\title{
Europeanization of sub-Arctic environments: perspectives from Norse Greenland's outer fjords
}

\author{
Kirsty A. Golding ${ }^{1}$, Ian A. Simpson ${ }^{1 *}$, Clare A. Wilson ${ }^{1}$, Emily C. Lowe ${ }^{2}$, J. Edward \\ Schofield $^{3}$, Kevin J. Edwards ${ }^{4}$
}

${ }^{1}$ Biological and Environmental Sciences, School of Natural Sciences, University of Stirling, FK9 4LA, Scotland, UK

${ }^{2}$ Department of Earth and Planetary Sciences and Department of Anthropology, Harvard University, 20 Oxford Street, Cambridge MA 02138 USA.

${ }^{3}$ Department of Geography \& Environment, School of Geosciences, University of Aberdeen, Elphinstone Road, Aberdeen, AB24 3UF, Scotland, UK

${ }^{4}$ Departments of Geography \& Environment and Archaeology, School of Geosciences, University of Aberdeen, Elphinstone Road, Aberdeen, AB24 3UF, Scotland, UK

*Corresponding author; Tel: +44 1786 467850, Email: i.a.simpson@stir.ac.uk

\begin{abstract}
Europeanization of sub-Arctic environments by Norse communities in Greenland, from the early $11^{\text {th }}$ to mid $15^{\text {th }}$ centuries AD, varied spatially and temporally, with pastoral agriculture and associated homefield management at the heart of this transformation. This process is poorly understood for the outer fjord areas of Norse Greenland, and from this locality we contribute a homefield soils and sediments-based analysis. Our findings identify a recipe effect - the partitioning of turf, domestic animal manure and domestic waste resources used to manage soil fertility, field irrigation channels and the effects of eroded material deposition in the homefield. These management practices increased soil macro-nutrient status relative to pre-settlement concentration in some areas of the homefield, whilst macro-nutrient concentrations in other areas of the homefield were allowed to decline. We suggest that where resources were limited, sustainable intensification could only be achieved in some areas of the homefield with others areas managed unsustainably.
\end{abstract}

Key words Europeanization; sub-Arctic; Norse Greenland; anthrosols; sustainable intensification 


\section{Introduction}

Norse Greenland is providing new and important understandings of European settlement and its social and environmental outcomes in sub-Arctic landscapes. Implementation of European-style land resource management from the early part of the 11th century AD (landnám: Old Norse - 'land-taking') caused substantial landscape transformations in Greenland (Amorosi et al., 1997). Native woodland and scrub were cleared in order to extend areas of grassland pasture and create hayfields to maintain domestic livestock for status, milk and meat (Amorosi et al., 1998). Turves were stripped for building materials (Roussell, 1941; Ólafsson \& Ágústsson, 2006), and peats were cut for fuel (Schofield et al. 2008) resulting in a more open cultural landscape (Fredskild, 1988; Gauthier et al., 2010; Edwards et al. 2011). Culturally-driven landscape change was further accelerated by extensive grazing over already fragile land surfaces, resulting in widespread soil erosion (Jacobsen, 1987), although this interpretation has been disputed by Kuijpers \& Mikkelsen (2009) who favour natural causes beginning at or around the turn of the first millennium AD.

Long-term activities which sustained domestic livestock in these landscapes included development and management of the homefield, used to produce much of the fodder required to feed animals stalled in byres and pens over the winter period (Amorosi et al., 1997). Manuring of these areas to sustain soil fertility is evident at Garðar/Igaliku in the Eastern Settlement (Buckland et al., 2008; 2009), and at Gården under Sandet (GUS) in the Western Settlement (Schweger, 1998; Ross \& Zutter, 2007; Hebsgaard et al., 2009). The introduction of irrigation systems buffering against periods of drought induced by föhn winds (Adderley \& Simpson, 2006), and recognised at Igaliku (Ingstad, 1966; Krogh, 1967; Buckland et al., 2009; Panagiotakopulu \& Buckland, 2012; Edwards \& Schofield 2013) and at Brattahlið/Qassiarsuk (Arneborg, 2005) further emphasises the importance of the homefield in fodder production and as part of the domestic livestock economy.

From the 14th century AD onwards, pastoral agriculture appears to have become less viable as the primary means of Norse subsistence. This is at least in part due to climatic deterioration associated with the onset of the Little Ice Age (LIA; Berglund, 1986; Barlow et al., 1997; Matthews \& Briffa, 2005) and land degradation (Jakobsen, 1991; Mainland, 
2006). Dietary evidence (Arneborg et al., 1999, 2012) and midden stratigraphies (Simpson \& Adderley, 2007) indicate shifts in emphasis towards maritime hunting (particularly of seals) during the later stages of settlement. The permanent abandonment of settlements accelerated in the late 14th century and into the 15th century as communities failed to anticipate and adapt to the conjunctures of falling temperatures, increased storminess, land degradation and isolation from emerging proto-world trade systems (Berglund, 1986; Jacobsen \& Jakobsen, 1986; Jacobsen, 1987; McGovern, 1980; 2000; Edwards et al., 2011; Dugmore et al., 2012).

Discussion of Norse-driven landscape change in both the Western and Eastern Settlements of Greenland has so far focused on settlements in the upper and middle reaches of fjord areas where farmsteads were concentrated. By contrast, there has been little attempt to understand landscape change in outer fjord areas of the Eastern Settlement (Norse settlement was absent from the outer fjord areas of the Western settlement). In areas towards the outer coast, the inter-relationships of an oceanic climate, dispersed settlement pattern, the possibility of Norse interaction with Inuit and the likely occurrence of harbour sites linking Greenland to Europe, points to a context that was distinctly different from that in other areas of Greenland (Golding et al., 2011). To address this imbalance we consider the coastal site of Sandhavn (Figure 1) in the Eastern Settlement, where a complex cultural landscape of Norse agricultural activity, structures associated with harbour-based trade and Inuit settlement are evident. Earlier research within this landscape (Golding et al., 2011) identified fossil anthropic soils, archaeological sediments and re-deposited (eroded) material within Norse homefield areas. Rising grass pollen influx also indicated intensification in hay production over the period ca. AD 1260-1350 despite climate deterioration. Within the setting of this site, the objectives for this paper are to establish the nature of soils inherited at settlement and from this evidence to identify homefield management practices that contributed to the observed intensification of hay production. In doing so, we offer prospective insight into the sustainability of historical European agricultural settlement in sub-Arctic environments. 


\section{Study area}

\subsection{Archaeology}

Sandhavn $\left(59^{\circ} 59^{\prime} \mathrm{N}, 44^{\circ} 46^{\prime} \mathrm{W}\right)$ is located on the coast in the southern part of the Norse Eastern Settlement within a sheltered bay that extends north-northwest from the coast for $1.5 \mathrm{~km}$ (Figure 2). The site features three clusters of Norse ruins identified as Ø221, Ø221a and $\varnothing 221 \mathrm{~b}$ during archaeological surveys of the Eastern Settlement by the National Museums of Denmark and Greenland (Christiansen, 2002). The ruins of the main farmstead (Ø221) are distributed across gently sloping terrain stretching $500 \mathrm{~m}$ inland from the coast and on the northern edge of a homefield with upper and lower areas recognised through soil survey of Ap horizons (cf. Golding et al., 2011). The lower homefield area is visible in Figure 2, where soil surveys (ibid.) identified irrigation channels placed to divert water from the stream into the lower homefield. The remains of a Thule winter dwelling, Inuit structure 6 (Rauhaage et al., 2003) are found towards the western edge of the homefield. Ruin Ø221a (a single, isolated structure) is situated a few hundred metres along the coast adjacent to the warehouse cliff, interpreted as a docking point utilised by Norwegian and Icelandic cargo vessels for loading and unloading cargo (Mikkelsen et al., 2001). It is thought that $\varnothing 221$ a functioned as a storage building for import-export goods associated with North Atlantic trade (Christiansen, 2002), although a shieling role (haystorage) has also been suggested for this building (Albrethsen, 1991). To the north-west, across the River Maakkarneq, lie the remains of two circular fold-type structures and several animal shelters (collectively group Ø221b) which are indicative of sheep rearing in the vicinity of the farm.

\subsection{Sandhavn homefield chronostratigraphies}

As first identified by Golding et al., (2011), soil and sediment stratigraphies within the homefield comprise four distinct units (Figures 3 and 4 and with profiles from beyond the homefield area serving as contrasting controls). An underlying buried podsol typically comprises a thin $(\sim 4 \mathrm{~cm})$ organic sandy loam layer (Ab horizon; soils notation follows the

FAO World Reference Base for Soil Resources [IUSS Working Group WRB, 2006]), representing the land-surface prior to Norse occupation, with various dark brown and 
greyish brown sands (Bb horizons). These horizons are superimposed on a light brownish grey or dark yellowish brown freely draining sand (BC horizon). Above the buried soil, accumulation of dark brown, very dark brown and dark yellowish brown (B horizon materials) eroded sands separate the buried podsol from an overlying anthrosol. The formation of a single dark brown sandy silt loam/sandy loam surface horizon (Ap horizon) across the lower homefield is attributed to the long-term addition of waste materials associated with manuring. Topsoil within the upper homefield comprises three phases of manuring activity (Ap horizons) separated by thin bands of $(\sim 2 \mathrm{~cm})$ of dark brown sand. The accumulation of deep, spatially discrete midden sediments in the lower homefield is attributed to processes of refuse discard. Waste deposits are also evident lining the irrigation channel found in the lower homefield.

The site's radiocarbon sequence was constructed from a series of small Betula and Salix charcoal fragments found in soil and sediment stratigraphic units across the site (Figure 5; Golding et al., 2011). A cautious interpretation of the site's radiocarbon sequence was made given the existence of a ${ }^{14} \mathrm{C}$ plateau and a pronounced ${ }^{14} \mathrm{C}$ wiggle during our periods of interest. The earliest activity is most likely from the early to mid-11th century AD; activity on the $\mathrm{Ab}$ horizon is coincident with the onset of soil amendments creating the Ap horizon. Land management included the introduction of irrigation channels, possibly repaired during the mid- $13^{\text {th }}$ to $14^{\text {th }}$ centuries, and was interrupted by two phases of land degradation with sand accumulating in the homefield. Midden accumulation commenced during the late $13^{\text {th }}$ century and land management is most likely to have ceased by the late $14^{\text {th }}$ century AD. This is earlier than the 1408 record for the marriage at the church in mid-

fjord Hvalsey (Nyegaard, 2009-10), and certainly before the mid-15th century date given for the abandonment of the Eastern Settlement (Berglund, 1986).

\section{Methodology}

\subsection{Thin section micromorphology}

Twelve undisturbed soil samples were collected in $8 \times 5 \times 4 \mathrm{~cm}$ Kubiena tins from five soil pits along a slope transect across the homefield (Figure 3). A further ten samples were 
collected from soil pits dug through two irrigation channels and a Norse midden. Sampling was designed to capture the maximum range of horizons and contexts. Thin sections were manufactured using standard methods (University of Stirling, 2011) and were examined using an Olympus BX-50 polarising microscope at x10-400 magnifications. Light sources included plane polarized (PPL), cross-polarized (XPL) and oblique incident (OIL). Semiquantitative slide description followed internationally accepted terminology (Bullock et al., 1985; Stoops, 2003) and is presented in summary tables (Tables 1, 3 and 4) together with images of key features, microstructures and micro-stratigraphies (Figure 6). Charcoal and bone abundances were quantified; a $0.5 \mathrm{~cm}$ square grid on acetate was superimposed on thin sections and the percentage abundance of charcoal/bone fragments was estimated for each square enabling the calculation of a mean abundance value (\%) for each investigated context. Squares covering more than one context were excluded. Data were not normally distributed and contained unequal sample populations. Multiple comparisons between key horizons and contexts were therefore made using a Kruskal-Wallis test in association with a Dunn's (post hoc) test. Semi-quantitative and quantitative data were directly assessed and interpreted against North Atlantic ethnographic and experimental micromorphology datasets of turf and domestic livestock manures, construction materials, fuel residues, kitchen wastes and occupation surfaces (Simpson et al., 2003; Adderley et al., 2006; Milek, 2012).

SEM-EDS analysis (Zeiss EVO-MA15 with an Oxford Instruments InCA Max $80 \mathrm{~mm}$ EDS) was used to determine macro-nutrient element composition ( $\mathrm{Mg}, \mathrm{P}, \mathrm{K}$ and $\mathrm{Ca}$ ) of ped fine ground mass in microstratigraphic horizons. Low vacuum conditions were used (60 $\mathrm{Pa}$ ) to prevent charging of the sample surface; strict operating conditions of $50 \mu \mathrm{A}$ filament current, 2.525 A gun current, $20 \mathrm{kV}$ accelerating voltage, and an $8.5 \mathrm{~mm}$ working distance to achieve an acquisition rate of $15 \mathrm{kcps}$, were applied to standardise the analyses. A polished Co standard was analysed every 2 hours to adjust for beam current drift and a polished dolomite standard was used for each horizon analysed to confirm the accuracy of the calculated absolute element concentrations. Navigation on the sample was aided by scanned sections and with five areas of interest (x 150 magnification) arranged in a ' $w$ ' pattern within micro-horizons. Element data from five points were collected from each area of interest giving 25 data points for each micro-horizon. Data are reported as non- 
normalised percentage weights. Multiple comparisons between the element loadings of key horizons were made using ANOVA tests in association with Tukey's (post hoc) test.

\subsection{Palynology}

Six samples were collected for pollen analysis from the cleaned face of an open pit dug into the presumed midden located adjacent to the Norse buildings. The samples were spaced at regular $(8 \mathrm{~cm})$ intervals and covered almost the full extent of the deposit (this being $\sim 10-58$ $\mathrm{cm}$ below the modern ground surface). The pollen samples were analysed to complement the micromorphological analyses. It was anticipated that the pollen content could potentially provide information on the sources of waste that were deposited on the midden.

Pollen samples were prepared and analysed according to standard procedures as outlined in Moore et al. (1991) and described in detail in Golding et al. (2011). Pollen samples were counted to a sum in excess of 300 TLP (total land pollen; collectively, the pollen from trees, shrubs, heaths and herbs). Microscopic charcoal in the pollen residues was quantified using the point count method of Clark (1982) and the charcoal data are presented on the pollen diagram as charcoal to pollen ratios $(\mathrm{C}: \mathrm{P})$. Principal components analysis $(\mathrm{PCA})$ of the six pollen samples from the midden was performed using PC-ORD software (McCune \& Mefford, 1999). Two pollen samples from the wall packing of the Inuit structure (Golding et al. 2011) and four late (post-AD 1250) Norse age pollen samples analysed from a mire located adjacent to the homefield (ibid.) - and broadly equivalent in age to those samples taken from the midden - were also included in the ordination for comparative purposes.

\section{Results and discussion}

\subsection{Landnám soils}

The Ab horizon ( $4 \mathrm{~cm}$ in thickness) is evident in homefield profiles (HP2), (HP3) and (HP4) (Table 1). This represents the original land surface prior to and at Norse occupation, comprising moderately sorted coarse mineral material beneath which are well-sorted and 
freely drained B horizon sands. The thin organo-mineral rich nature of this former surface horizon is consistent with short growing seasons, but with channel microstructures indicating biological activity that has resulted in a well humified and stable Ab horizon. Charcoal fragments may indicate burning around the time of landnám (Table 2) but given the variability and low charcoal abundance across the former land surface this is likely to represent domestic hearth residues blown or washed into profiles rather than spatially discrete land clearance activity. Cumulative concentrations of the measured macronutrients in $\mathrm{Ab}$ horizons (weight \%; Table 2) ranges from 1.19 - 1.65\%; the relative concentrations of the different elements fluctuate although $\mathrm{Mg}$ is consistently the smallest component.

Sand deposits ( $\sim 3 \mathrm{~cm}$ in thickness) covering the Ab horizon within homefield profiles HP1, HP2 and HP4 are characterised by contrasts in arrangement and abundance of coarse mineral material (Table 1). The HP1 and HP2 horizons are single grain micro-structured, well sorted and quartz-grain dominated suggesting they represent deposits of wind-blown sand. This is in contrast to the equivalent horizon in HP4 where microstructures are moderately sorted with intergrain microaggregate microstructures and are rock fragmentdominated, indicating a colluvial origin from slope instability (Figure $6[b]$ ). The accumulation of sand and silt deposits as evidence of the initial impact of Norse settlement is observed elsewhere in Greenland (Massa et al., 2012) and more widely in the North Atlantic region where erosion is followed by a period of landscape recovery (Adderley et al., 2008; Brown et al., 2012). Colluvial deposits have not previously been observed in North Atlantic homefield stratigraphies. At Sandhavn the formation of the anthropic Ap horizon commenced immediately after initial impact.

\subsection{Homefield management}

The single dark brown and brown Ap horizon within the lower homefield area ranges in thickness from $8-18 \mathrm{~cm}$ and is the result of sustained additions of waste materials associated with soil amendment. Much of this horizon derives from uncarbonised turf, enhancing coarse organic material occurrences, with an attached poorly-sorted and coarse mineral component. Finely comminuted organic material associated with larger organic (turf) fragments indicates that this material was used as livestock bedding and represents 
plaggen manuring processes (Table 3). A secondary amendment material evident in the lower homefield Ap horizon consists of Betula and Salix charcoal fragments indicating scrub-wood fuel residues. Differences in charcoal abundance between HP3 and HP1/HP2 (Table 2), significantly more abundant in HP3 compared to HP1 and HP2 ( $<<0.05)$, may reflect preferential amendment of areas across the lower homefield. Mixes of turf and manure with the charcoals suggests that the amendment materials were composted. Excremental fine organo-mineral materials indicate that amendment activity led to enhanced biological activity. Accumulation of a well-sorted mineral micro-horizon in profile (HP2) suggests that amendment was taking place against a backdrop of occasional localised landscape instability. Cumulative concentrations of measured macro-nutrients in the lower homefield Ap horizons (\% weight, Table 2) ranges from 0.74-0.96\% and with a consistency in relative elemental concentrations of $\mathrm{P}>\mathrm{K}>\mathrm{Ca}>\mathrm{Mg}$. The contrast with the underlying $\mathrm{Ab}$ horizon is of particular interest as plaggen-type manuring generally improves nutrient reserves (Blume \& Leinweber, 2004; Simpson, 1997). Here it is clear that amendment activity failed to do this, suggesting the application of nutrient-poor manures and turves and that amendment with the associated stripping of turf from the surrounding landscape would have had the effect of degrading the wider agricultural landscape for no discernible gain.

Within the lower homefield irrigation profile (IP1) the rectangular-shaped channel structure is lined with silty loam typically $2-3 \mathrm{~cm}$ in thickness (context [6]). The channel crosssection measures $10 \times 15 \mathrm{~cm}$ and is overlain by a discrete unit of brown loamy sand (context [2]). As in the amended soils, Context 6 (Table 4) is derived from turf and livestock wastes, scrub-wood fuel residues and kitchen wastes. The distinctive vughy microstructure with corresponding close porphyric-related distribution indicates that this organic-rich material has been deliberately compacted as a channel lining designed to limit permeability to underlying sands. Low concentrations of measured macro-nutrients (cumulative weight \% of $0.63 \%$; Table 2) together with the absence of Fe-based pedofeatures in thin section, indicate that this material was not waterlogged for extended periods of time unsurprisingly as irrigation would have been periodic. The organo-mineral, refuse-rich nature of context 2 and enhanced macro-nutrient reserves (cumulative weight $\%$ of $1.23 \%$; Table 2) are consistent with culturally amended topsoils, and is thus interpreted as evidence for the continuation of manuring after the irrigation channel had fallen into disuse. The 
occurrence of mineral micro-horizons (context 2[b]) throughout context 2 is considered to reflect ongoing erosion in the lower homefield during the latter stages of agricultural activity. This suggests that active sediment removal from the channel would have been required to maintain flow.

Topsoil within the upper homefield area comprises three dark brown Ap horizons (Ap1, Ap2, and Ap3), typically $5 \mathrm{~cm}$ in thickness and separated by two thin bands $(\sim 2 \mathrm{~cm})$ of sand (context [3] and [5]) (Figure 6). Amendment and biological activity in each of the Ap horizons is similar to the lower homefield; additionally traces of bone fragments indicate the application of kitchen waste (Table 3). There is a linear pattern to the deposition of amendment material with sequences of turf-based material and charcoal giving further support to the interpretation of composting prior to addition to the homefield. Charcoal is evident in all three Ap horizons totalling 3.2\% (Ap1), 4.3\% (Ap2) and 3.2\% (Ap3) respectively (Table 2). No significant difference was found in the charcoal abundance between horizons with applications rates consistent over time. However, significant differences in charcoal content are evident between the upper and lower homefields $(p<0.05)$ indicating enhanced intensity of application in the upper homefield. Together with the evidence of kitchen waste this implies different recipes of amendment being used in different areas. Evidence of enhanced amendment is reflected in cumulative concentrations of measured macro-nutrients (weight \%, Table 2) ranging from 1.24-1.42\% with $\mathrm{P}>\mathrm{K}>\mathrm{Ca}>\mathrm{Mg}$. It is also reflected in remarkable uniformity in $\mathrm{P}$ concentrations, mirroring the charcoal and bone abundances and greater than the underlying Ab horizon cumulative macro-nutrient concentrations of $1.19 \%$. Here enhanced amendment activity did bring macro-nutrient reserves above those evident in landnám soils further emphasising the distinction between the upper and lower homefield areas. Within the upper homefield, contexts 3 and 5 (Table 3 ) are characterised as predominantly poorly-sorted rock fragment and quartz accumulations representing distinct episodes of colluvial erosion and deposition during the later stages of manuring activity.

\subsection{Midden accumulations}

The midden comprises a $20 \mathrm{~cm}$ black sandy loam deposit (context [3]) above which lies a layer of very dark brown sandy silt loam (context [2]) ranging in thickness from 30 to 40 
cm. Contexts 2 and 3 are compacted and poorly sorted (Table 4). Combinations of bone and burned bone are present throughout the midden ranging in abundance from $5.6 \%$ (context [2]) to $2.4 \%$ (context [3]) (Table 2). Similarly, charcoal was found to be significantly more abundant in context $2(7.3 \%)$ than context $3(5.5 \%),(\mathrm{p}<0.05)$. Cumulative concentrations of measured macro-nutrients (weight \%, Table 2) are at a maximum for the Sandhavn landscape at $2.33 \%$ for context 3 and $2.07 \%$ for context 2; relative concentrations are variable. Differences in the abundance of bone/charcoal fragments between contexts are difficult to interpret from our ethnographic and experimental data sets. However, the sediment features and properties of the Sandhavn midden are similar to the occupational debris associated with the later phases of midden accumulation at the inner fjord site of Brattahlið, where a marked shift from debris including animal manures to domestic waste is observed (Simpson \& Adderley, 2007).

Pollen samples from the midden are displayed on Figure 7. The assemblages are nearhomogenous throughout the profile and pollen concentrations are high (in the range 90,000-300,000 grains $\mathrm{cm}^{-3}$ ), although the standard of preservation of microfossils is rather poor, with c. $20 \%$ TLP recorded as indeterminate in most samples (rising to $40 \%$ in the basal [54-55 cm] sample). Such high frequencies of deteriorated pollen grains may indicate that pollen assemblages have undergone post-depositional change. This can result in biased counts and possibly erroneous palaeoecological interpretations (Hall, 1981). The approach taken in the interpretation of the samples presented here is a cautious one and the assemblages should not necessarily be considered to reflect a complete picture of the wider (natural) vegetation communities across the site during the Norse period, but rather as a tool for fingerprinting waste streams entering the midden.

The pollen assemblages are dominated by Poaceae (grass). This pollen type approaches or exceeds $80 \%$ TLP in every sample and may reflect both the input to the midden of grass pollen contained in animal dung (cf. Buckland et al., 2009; and discussed further below) and the trapping of grass pollen liberated directly from local sources (e.g. the adjacent hayfields); the balance between these is uncertain. The pollen assemblages contain a range of microfossil indicators typical of Norse North Atlantic environments (Fredskild, 1988; Edwards et al., 2011). These include pollen from weeds of disturbed habitats (e.g. Cerastium-type, which is probably representative of Stellaria media [common chickweed]; 
cf. Fredskild [1978]), and plants typical of nutrient-enriched situations (e.g. Montia fontana [blinks]), both of which may have been growing directly on or around the midden. The ordination diagram (Figure 8) indicates that there is very little difference in the overall composition of late Norse age (ca. AD 1200-1400) pollen assemblages across the site.

Of particular interest are the coprophilous fungal spores contained within the pollen assemblages. Sporormiella-type (HdV-113) and Sordaria-type (HdV-55A) have been identified as key indicators for the past presence of grazing herbivores both around Norse farmsteads (Schofield \& Edwards, 2011) and wider afield (e.g. van Geel et al., 2003; Gill et al., 2009; Baker et al., 2013). Thus occurrences of coprophilous spores might be anticipated in any sedimentary context into which there was substantial input of animal dung. The frequencies of spores registered in the midden samples from Sandhavn, however, are relatively low (HdV-55A and -113 rarely exceed 1\% TLP in any sample). This could indicate that animal dung was being taken directly from the byre to be added as fertilizer to the homefield rather than being collected and dumped as waste on the midden. Considering the large quantity of microscopic charcoal and rotted bone observed in the midden, this suggests that the midden deposit may largely comprise kitchen or other household waste streams (e.g. from hearths) rather than waste bedding and dung from the byre.

\section{Conclusions}

The narrative emerging from homefield soil and sediments analyses at Sandhavn adds prospective new aspects to the novel and nuanced land resource management and organisation practices which are seemingly increasingly evident in the sensitive and changing environments of the Norse North Atlantic. These include fuel resource management (Simpson et al., 2003), a range of environmentally sensitive grazing regimes (Thomson \& Simpson, 2007; Brown et al., 2011) and homefield management for barley and hay (Simpson et al., 2002; Adderley et al., 2008). Setting our findings from outer fjord Sandhavn against current understanding of landscape management in Norse Greenland, would indicate important new elements in the Europeanization of the Greenlandic landscape. The Norse community at Sandhavn inherited soils that were stable, biologically active and with moderate concentrations of macro-nutrient reserves, although shallow 
rooting depths and short growing seasons restricted agricultural potential. Attempts to enhance the homefield soil resources included selection of wastes, composting, and deliberate application of different manuring recipes to different areas of the homefield. The effect of these contrasts in application on homefield soils is pronounced.

In the upper homefield kitchen waste, turves and manure were used together with greater applications of fuel residues, resulting in enhanced macro-nutrient concentrations relative to the landnám soils. In contrast, there was substantial reduction in topsoil macro-nutrient concentrations in the lower homefield, where kitchen waste use was absent and fuel residue use was less. This is the first recorded evidence of a recipe effect in Greenland, and has not previously been considered in discussions of amendment practices (Buckland et al., 2009; Hebsgaard et al., 2009; Simpson et al., 1999). Furthermore, the use of compost materials along with kitchen waste as a lining for irrigation channels to reduce water loss in an otherwise well-drained environment is a second land management practice seen for the first time. This will influence calculations of required water storages and soil moisture deficits in Norse irrigation systems (Adderley \& Simpson, 2006).

Partitioned and allocated use of wastes suggests a husbanding of available resources, resulting in one part of the homefield becoming nutrient enhanced while another part suffered relative nutrient decline. These observations indicate finite resources to manage homefields - in terms of waste streams or worker availability for instance - and concentration to ensure maximum hay productivity from at least one plot. Cooling climatic conditions may have influenced this adaptive land management approach, with heavily fertilised homefields demonstrated to offset climatically-driven declines in productivity (Simpson et al., 2002). A less-likely scenario is that the more intensively fertilised area could have been managed for the cultivation of barley (Hordeum vulgare). Records of pollen and plant macro-remains indicate that the sowing of barley may have been attempted at farms situated around the (sub-continental) upper fjords (Henriksen, 2012; Ledger et al., 2014; Edwards, in press), but similar evidence has yet to emerge for (cooler oceanic) outer fjord areas, including Sandhavn.

A consequence of Europeanization of the Sandhavn landscape is the persistent evidence of land degradation. Although this has been seen elsewhere at the landscape-scale in the 
Eastern Settlement (Edwards et al., 2008; Schofield et al., 2010), at Sandhavn we see eroded soils as well as colluvial deposits directly influencing the managed homefield area. Sand microstratigraphies and rock fragments observed in thin section are clear evidence for soil erosion and slope movement in the surrounding landscape, with deposition immediately following first occupation. Subsequent episodes of eroded soils and colluvial material deposition are evident throughout the period of homefield management. New amendment efforts are recorded after each discernible episode of erosion, stabilising the land surface and creating a new agricultural soil.

The outcome of Norse homefield management at Sandhavn is a sustainable intensification in one area of the landscape to improve fodder quality and productivity and to enhance the soil resource base (Pretty, 2008; Franks, 2014). As a consequence, an adjacent area is inferred to have continued in use, but with the soil resource base there deteriorating from its pre-settlement condition. This juxtapositioning of sustainable and unsustainable land management is a distinctive characteristic of Europeanization at Sandhavn and gives a wider resonance to our study. It suggests that in a Greenlandic European agricultural context, where resources were limited, land management priorities were set and sustainable intensification could only be achieved with unsustainable land management in other areas of the farm. From our historical perspective, we can say that despite the general deterioration in climate and marked short-term climatic fluctuations in the region of the Eastern Settlement, evident almost from the onset of Norse settlement through to its demise (Kaufman et al., 2009; Vinther et al., 2010; Massa et al., 2012), the Norse community at Sandhavn established and maintained homefield activity during a cooling 12th century, expanded activity during the more substantial climate downturns of the 13th century, and continued to enable the intensification of grassland production into the extended cold periods of the 14th century until landscape abandonment (Golding et al., 2011). Our analyses suggest a homefield management strategy that emphasised sustainable intensification of soil macro-nutrients, even as other areas were being run down, and this provided effective and persistent agricultural resilience in the face of climatic perturbations for several generations of Norse settlers. Ultimately, local sustainable intensification of the landscape may only be as effective as the broader social framework in which it is found. 


\section{Acknowledgements}

The authors gratefully acknowledge the financial support of the Leverhulme Trust

Footprints on the Edge of Thule Programme Award. ECL acknowledges the support of the Weissman International Internship Program, the Department of Earth and Planetary

Sciences and the Department of Anthropology at Harvard. We would also like to thank George McLeod (University of Stirling) for manufacturing soil thin sections. 


\section{References}

Adderley, P.A., \& Simpson, I.A. (2006). Soils and palaeo-climate based evidence for irrigation requirements in Norse Greenland. Journal of Archaeological Science 33: 16661679 .

Adderley, W.P., Simpson, I.A. \& Davidson, D.A. (2006). Historic landscape management: a validation of quantitative soil thin section analyses. Journal of Archaeological Science 33: 320-334.

Adderley, W.P., Simpson, I A. \& Vésteinsson, O. (2008). Local-scale adaptations: a modeled assessment of soil, landscape, microclimatic, and management factors in Norse home-field productivities. Geoarchaeology 23: 500-527.

Albrethsen, S.E. (1991). Saeters in the Norse Eastern Settlement of Østerbygden in southwest Greenland. Acta Borealia 1: 15-28.

Amorosi, T., Buckland, P.C., Dugmore, A., Ingimundarson, J.H., \& McGovern, T.H. (1997). Raiding the landscape: human impact in the Scandinavian North Atlantic. Human Ecology 25: 491-518.

Amorosi, T., Buckland, P.C., Edwards, K.J., Mainland, I., McGovern, T.H., Sadler, J.P. \& Skidmore, P. (1998). They did not live by grass alone: the politics and paleoecology of animal fodder in the North Atlantic. Environmental Archaeology 1: 41-54.

Arneborg, J. (2005). Greenland irrigation systems on a West Nordic background. An overview of the evidence of irrigation systems in Norse Greenland c.980-1450 AD. Památky Archeologickè-Supplementum 17, Ruralia V: 137-145.

Arneborg, J., Heinemeier, N., Lynnerup, N., Nielsen, H.L., Rud, N. \& Sveinbjorsdóttir, A.E. (1999). Change of diet of the Greenland Vikings determined from stable carbon isotope analysis and ${ }^{14} \mathrm{C}$ dating of their bones. Radiocarbon 14: 157-168.

Arneborg, J., Lynnerup, N. \& Heinemeier, J. (2012). Human diet and subsistence patterns in Norse Greenland AD c.980-AD c.1450: archaeological interpretations. Journal of the North Atlantic, Special Volume 3: 119-133. 
Baker, A.G., Bhagwat, S.A. \& Willis, K.J. (2013) Do dung fungal spores make a good proxy for past distribution of large herbivores? Quaternary Science Reviews 62: 21-31.

Barlow, L.K., Sadler, J.P., Ogilvie, A.E.J., Buckland, P.C., Amorosi, T., Ingimundarson, J.H., Skidmore, P., Dugmore, A.J. \& McGovern, T.H. (1997). Interdisciplinary investigations of the end of the Norse Western Settlement in Greenland. The Holocene 7: 489-499.

Berglund, J. (1986). The decline of the Norse settlements in Greenland. Arctic Anthropology 23: 109-135.

Blume, H.-P. \& Leinweber, P. (2004). Plaggen soils: landscape history, properties and classification. Journal of Plant Nutrition and Soil Science 167: 319-327.

Brown, J.L., Simpson, I.A., Morrison, S.J.L., Adderley, W.P., Tisdall, E. \& Vésteinsson, O. (2012). Shieling areas: historical grazing pressures and landscape responses in northern Iceland. Human Ecology 40: 81-99.

Buckland, P.C., Edwards, K.J., Panagiotakopulu, E. \& Schofield, J.E. (2008). Land management at the bishop's seat, Garðar, medieval Greenland. Antiquity 82, 315: http://antiquity.ac.uk/ProjGall/buckland315

Buckland, P.C., Edwards, K.J., Panagiotakopulu, E. \& Schofield, J.E. (2009). Palaeoecological evidence for manuring and irrigation at Garðar (Igaliku), Norse Eastern Settlement, Greenland. The Holocene 19: 105-116.

Bullock, S., Fedoroff, N., Jongerius, A., Stoops, G. \& Turisna, T. (1985) Handbook for soil thin section description. Waine Research Publications, Wolverhampton.

Christiansen, D.V. (2002). Handel og kommunikation I Nordatlanten. Rapport om prøveundersøgelser på den formodede atlanthavn, Sandhavn ved Maakkarneq, Nanortalik Kommune, sommeren 2001. Feltrapport 3. SILA Nationalmuseets Center for Grønlandsforskning, Copenhagen.

Clark, R.L. (1982). Point count estimation of charcoal in pollen preparations and thin sections of sediments. Pollen et spores 24: 523-535. 
Dugmore, A.J., McGovern, T.H., Vésteinsson, O., Arneborg, J., Streeter, R. \& Keller, C. (2012). Cultural adaptation, compounding vulnerabilities and conjunctures in Norse Greenland. PNAS 109: 3658-3663.

Edwards, K.J. (In press). Early farming, pollen and landscape impacts from northern Europe to the North Atlantic: conundrums. In Gulløv, H.C. (ed.), Northern Worlds landscapes, interactions and dynamics. PNM, National Museum of Denmark, Copenhagen.

Edwards, K.J., Erlendsson, E. \& Schofield, J.E. (2011). Is there a Norse 'footprint' in North Atlantic pollen records? In Sigmundsson, S., Holt, A., Sigurðsson, G., Ólafsson, G. \& Vésteinsson, O. (eds) Viking settlements and society: papers from the Sixteenth Viking Congress, Reykjavík and Reykholt, 16-23 August 2009. Hið íslenska fornleifafélag and University of Iceland Press, Reykjavík, pp. 65-82.

Edwards, K.J. \& Schofield, J.E. (2013). Investigation of proposed Norse irrigation channels and dams at Garðar/Igaliku, Greenland. Water History 5, 71-92

Edwards, K.J., Schofield, J.E., Kirby, J.R. \& Cook, G.T. (2011). Problematic but promising ponds? Palaeoenvironmental evidence from the Norse Eastern Settlement of Greenland. Journal of Quaternary Science 26: 854-865.

Edwards, K.J., Schofield, J.E. \& Mauquoy, D. (2008). High resolution paleoenvironmental and chronological investigations of Norse landnám at Tasiusaq, Eastern Settlement, Greenland. Quaternary Research 69: 1-15.

Franks, J.R. (2014). Sustainable intensification: a UK perspective. Food Policy 47: 71-80

Fredskild, B. (1978). Palaeobotanical investigations of some peat deposits of Norse age at Qagssiarssuk, south Greenland. Meddelelser om Grønland 204: 1-41.

Fredskild, B. (1988) Agriculture in a marginal area - south Greenland from the Norse landnam (985 A.D.) to the present (1985 A.D.). In Birks, H.H., Birks, H.J.B., Kaland, P.E. \& Moe, D. (eds) The cultural landscape: past, present and future. CUP, Cambridge, pp. 381-394. 
Gauthier, E., Bichet, V., Massa, C., Petit, C., Vannière, B. \& Richard, H. (2010). Pollen and non-pollen palynomorph evidence of medieval farming activities in southwestern Greenland. Vegetation History and Archaeobotany 19: 427-438.

Gill, J.L., Williams, J.W., Jackson, S.T., Lininger, K.B. \& Robinson, G.S. (2009). Pleistocene megafaunal collapse, novel plant communities, and enhanced fire regimes in North America. Science 326: 1100-1103.

Golding, K.A., Simpson, I.A., Schofield, J.E. \& Edwards K.E. (2011). Norse-Inuit interaction and landscape change in southern Greenland? A geochronological, pedological and palynological investigation. Geoarchaeology 26: 315-345.

Hall, S.A. (1981) Deteriorated pollen grains and the interpretation of Quaternary pollen diagrams. Review of Palaeobotany and Palynology 32: 193-206.

Hebsgaard, M.B., Gilbert, M.T.P., Arneborg, J., Heyn, P., Allentoft, M.E., Bunce, M., Schweger, C. \& Willerslev, E. (2009). The farm beneath the sand - an archaeological case study on ancient 'dirt' DNA. Antiquity 83: 430-444.

Henriksen, P.S. (2012) Agriculture on the edge - the first finds of cereals in Norse Greenland. In Gulløv, H.C., Toft, P.A. \& Hansgaard, C.P. (eds) Northern worlds challenges and solutions. National Museum of Denmark, Copenhagen, pp. 174-177.

Ingstad, H. (1966). Land under the Pole Star. Jonathan Cape Ltd, London.

IUSS Working Group WRB (2006). World reference base for soil resources 2006. World Soil Resources Reports No. 103. FAO, Rome.

Jakobsen, B.H. 1991. Soil resources and soil erosion studies in Southern Greenland to estimate the natural resources in the Norse period. Acta Borealia 1: 56-68.

Jacobsen, N.K. (1987). Studies on soils and potential for soil erosion in the sheep farming area of south Greenland. Arctic and Alpine Research 19: 498-507.

Jacobsen, N.K. \& Jakobsen, B.H. (1986). ${ }^{14} \mathrm{C}$ datering af en fossil overfladehorisont ved Igaliku Kujalleq, Sydrønland, set i relation to nordboernes landnam. Geografisk Tidsskrift 86: 76-77. 
Kaufman, D.S., Schneider, D.P., McKay, N.P., Ammann, C.M., Bradley, R.S., Briffa, K.R., Miller, G.H., Otto-Bliesner, B.L., Overpeck, J.T., Vinther, B.M. \& Members, A.L.K.P. (2009). Recent warming reverses long-term arctic cooling. Science 325: 12361239.

Krogh, K.J. (1967). Viking Greenland. National Museum, Copenhagen.

Kuijpers, A. \& Mikkelsen, N. (2009) Geological records of changes in the wind regime over south Greenland since the Medieval Warm Period: a tentative reconstruction. Polar Record 45: 1-8.

Ledger, P.M., Edwards, K.J. \& Schofield, J.E. (2014). Vatnahverfi: a green and pleasant land? Palaeoecological reconstructions of environmental and land-use change. Journal of the North Atlantic, Special Volume 6: 29-46.

Mainland, I. (2006). Pastures lost? A dental microwear study of ovicaprine diet and management in Norse Greenland. Journal of Archaeological Science 33: 236-252.

Massa, C., Bichet, V., Gauthier, É., Perren, B.B., Mathieu, O., Petit, C., Monna, F., Giraudeau, J., Losno, R. \& Richard, H. (2012). A 2500 year record of natural and anthropogenic soil erosion in South Greenland. Quaternary Science Reviews 32: 119-130.

Matthews, J.A. \& Briffa, K.R. (2005). The 'Little Ice Age': re-evaluation of an evolving concept. Geografiska Annaler 87A, 17-36.

McCune, B. \& Mefford, M.J. (1999). PC-ORD. Multivariate analysis of ecological data, version 4. MjM Software Design, Gleneden Beach, Oregon.

McGovern, T.H. (1980). Cows, harp seals, and church bells: adaptation and extinction in Norse Greenland. Human Ecology 8: 245-275.

McGovern, T.H. (2000). The demise of Norse Greenland. In Fitzhugh, W.W. \& Ward, E.I. (eds) Vikings: the North Atlantic Saga. Smithsonian Institute Press, Washington D.C., pp. 327-339. 
Mikkelsen, N., Kuijpers, A., Lassen, S., \& Vedel, J. (2001). Marine and terrestrial investigations in the Norse Eastern Settlement, south Greenland. Geology of Greenland Survey Bulletin 189: 65-69.

Milek, K.B. (2012). Floor formation processes and the interpretation of site activity areas: an ethnoarchaeological study of turf buildings at Thverá, northeast Iceland. Journal of Anthropological Archaeology 31: 119-137.

Moore, P.D., Webb, J.A. \& Collinson, M.E. (1991). Pollen analysis, $2^{\text {nd }}$ edition. Blackwell, Oxford.

Nyegaard, G. (2009-10). Restoration of the Hvalsey fjord church. Journal of the North Atlantic, Special Volume 2: 7-18.

Ólafsson, G. \& Ágústsson, H. (2006). The reconstructed medieval farm in Pjórsárdalur and the development of the Icelandic turf house. National Museum of Iceland and Landsvirkjun, Reykjavík.

Panagiotakopulu, E. \& Buckland, P.C. (2012) Irrigation at Garðar, SW Greenland and its North European context. Water History 4: 197-211.

Pretty, J. (2008). Agricultural sustainability: concepts, principles and evidence. Philosophical Transactions of the Royal Society B 363: 447-465.

Raahauge, K., Hoegh-Knudsen, P., Gulløv, H.C,, Mohl, J., Krause, C. \& Møller, N.A. (2003). Tidlig Thulekultur I Sydgrønland. Rapport om undersøgelserne I Nanortalik Kommune, sommeren 2002, Feltrapport 9. SILA Nationalmuseets Center for Grønlandsforskning, Copenhagen.

Ross, J.M \& Zutter, C. (2007). Comparing Norse animal husbandry practices: paleoethnobotanical analyses from Iceland and Greenland. Arctic Anthropology 44: 62-85.

Roussell, A. (1941). Farms and churches in the Mediaeval Norse settlements of Greenland. Meddelelser om Grønland 89: 1-354. 
Schofield, J.E. \& Edwards, K.J. (2011). Grazing impacts and woodland management in Eriksfjord: Betula, coprophilous fungi and the Norse settlement of Greenland. Vegetation History and Archaeobotany 20: 181-197.

Schofield, J.E., Edwards, K.J. \& Christensen, C. (2008). Environmental impacts around the time of Norse landnám in the Qorlortoq valley, Eastern Settlement, Greenland. Journal of Archaeological Science 35: 1643-1657.

Schofield, J.E., Edwards, K.J., Mighall, T.M., Martínez Cortizas, A., Rodríguez-Racedo, J. $\&$ Cook, G. (2010). An integrated geochemical and palynological study of human impacts, soil erosion and storminess from southern Greenland since c. AD 1000. Palaeogeography, Palaeoclimatology, Palaeoecology 295: 19-30.

Schweger, C.E. (1998). Geoarchaeology of the GUS site: a preliminary framework. In Arneborg, J. \& Gulløv, H.C. (eds) Man, culture and environment in ancient Greenland. Danish Polar Center Publication 4. Danish National Museum \& Danish Polar Center, Copenhagen, pp. 8-14.

Simpson, I.A. (1997). Relict properties of anthropogenic deep top soils as indicators of infield management in Marwick, West Mainland, Orkney. Journal of Archaeological Science 24: 365-380.

Simpson, I.A., \& Adderley, P.A. (2007). Geoarchaeological investigations at Qassiarsuk (Brattahlið). In Edvardsson, R. (ed.), Archaeological excavations at Qassiarsuk 2005-2006 field report (data structure report). Náttúrustofa Vestfjarða, NABO, Grønlands Nationalmuseum \& Arkiv, pp. 40-54.

Simpson, I.A., Adderley, W.P., Guðmundsson, G., Hallsdóttir, M., Sigurgeirsson, M. and Snæsdóttir, M. (2002). Soil limitations to agrarian land production in pre- modern Iceland. Human Ecology 30: 423-443.

Simpson, I.A., van Bergen, P.F., Elhmmali, M., Roberts, D.J. \& Evershed, R.P. (1999). Lipid biomarkers of manuring practice in relict anthropogenic soils. The Holocene 9: 223229.

Simpson, I.A., Vésteinsson, O., Adderley, W.P. \& McGovern, T.H. (2003). Fuel resource utilisation in landscapes of settlement. Journal of Archaeological Science 30: 1401-1420. 
Stoops, G. (2003). Guidelines for analysis and description of soil and regolith thin sections. Soil Science Society of America, Madison, Wisconsin,.

Thomson A.M. \& Simpson, I.A. (2007). Modeling historic rangeland management and grazing pressures in landscapes of settlement. Human Ecology 35: 151-168.

van Geel, B., Buurman, J., Brinkkemper, O., Schelvis, J., Aptroot, A., van Reenen, G. \& Hakbijl, T. (2003). Environmental reconstruction of a Roman Period settlement site in Uitgeest (The Netherlands), with special reference to coprophilous fungi. Journal of Archaeological Science 30: 873-883.

University of Stirling (2011) Thin section \& micromorphology.

http://www.thin.stir.ac.uk/category/methods/.

Vinther, B.M., Jones, P.D., Briffa, K.R., Clausen, H.B., Andersen, K.K., Dahl-Jensen, D. \& Johnsen, S.J. (2010). Climate signals in multiple highly resolved stable isotope records from Greenland. Quaternary Science Reviews 29: 522-538. 


\section{Figures and Tables}

Figure 1: Map showing the position of Sandhavn relative to other Norse farms in the outer fjords of the Eastern Settlement of Greenland. (Inset: the location of the Norse Eastern and Western Settlements in Greenland). Based on National Museum of Denmark and National Museum of Greenland surveys.

Figure 2: View south across the lower homefield beside Norse ruin group Ø221 (Sandhavn) with the position of the midden (M) also visible (demarcated by the dashed lines).

Figure 3: Map showing soil sampling locations in the homefield at $\varnothing 221$; the number of Kubiena tin samples taken from each soil profile is given in parentheses. The positions of archaeological and landscape features referred to in the text are also shown.

Figure 4: Stratigraphy and summary soil description of homefield profiles 1 (HP1), 2 (HP2), 3 (HP3) and 4 (HP4). The sampling locations of Kubiena tins are annotated. Soil texture classes: S - Sand; SL - Sandy loam; L - Loam; SSL - Sandy silt loam.

Figure 5: Probability distributions of radiocarbon dates for Sandhavn (modified from Golding et al. 2011). Differences in shading distinguish the samples from Norse (black) and Inuit (grey) contexts. The three prospective phases of site activity referred to in the text are annotated. See Golding et al. (2011) for further details regarding the radiocarbon dates and calibration procedures.

Figure 6: (a) Brown, organo-mineral micromass (Ab horizon, HP4); (b) Intergrain microaggregate microstructure (Context 5, HP2); (c) Coarse monic related distribution (Context 3, HP1); (d) Excremental fabric consisting of coalesced dense excremental microaggregates (Ap horizon, HP3); (e) Charcoal fragment embedded in a matrix of porous to dense excremental microaggregates (Ap1 horizon, HP4); (f) Charcoal fragments (Context 2, Midden); (g) Burned bone and degraded fungal sclerotium (Context 3, Midden), (h) Bone with clearly visible haversian canals (Context 2, Midden); (i) Irrigation channel lining (Context 6, IP1) with contrasting sand sub-soil beneath. All images are taken in plane polarised light.

Figure 7: Percentage diagram displaying selected taxa in pollen assemblages from the Norse midden at Sandhavn (+ indicates $<1 \%$ TLP). The midden contexts $[2,3]$ are described in the text (section 4.3). Four radiocarbon dates were taken through the midden 
(Golding et al., 2011). These returned statistically-indistinguishable dates within the envelope cal. AD 1260-1410, indicating that the pollen diagram presented here spans a period of no more than 150 cal. years.

Figure 8: Ordination diagram (PCA) displaying scores for late Norse age (13th-14th century AD) pollen samples from the midden (prefixed MID), the wall packing of the Inuit structure IS6 (WP), and the mire adjacent to the farmstead (M). Numbers following prefixes indicate the depth within the context (in $\mathrm{cm}$ below ground surface) from which each sample was taken. Pollen assemblages from the midden are presented in Figure 7, whilst assemblages from IS6 and the mire are published in Golding et al. (2011). The first two axes of the PCA (presented here) account for $44.8 \%$ of the variance within the dataset.

Table 1: Semi-quantitative thin section micromorphology descriptions of landnám soils, Sandhavn, Greenland.

Table 2: Quantitative date from thin section analyses of key soil and sediment horizons, Sandhavn, Greenland. Mean \% abundance of charcoal and bone fragments, and nonnormalised percentage weights of measured macro-nutrients. Charcoal and bone abundances marked - indicate that these features are absent. Columns with mean element concentrations that share a superscript letter are not significantly $(p<0.05)$ different.

Table 3: Semi- quantitative thin section micromorphology description of soils associated with homefield management, Sandhavn, Greenland.

Table 4: Semi-quantitative thin section micromorphology descriptions of irrigation features and midden accumulations, Sandhavn, Greenland. 


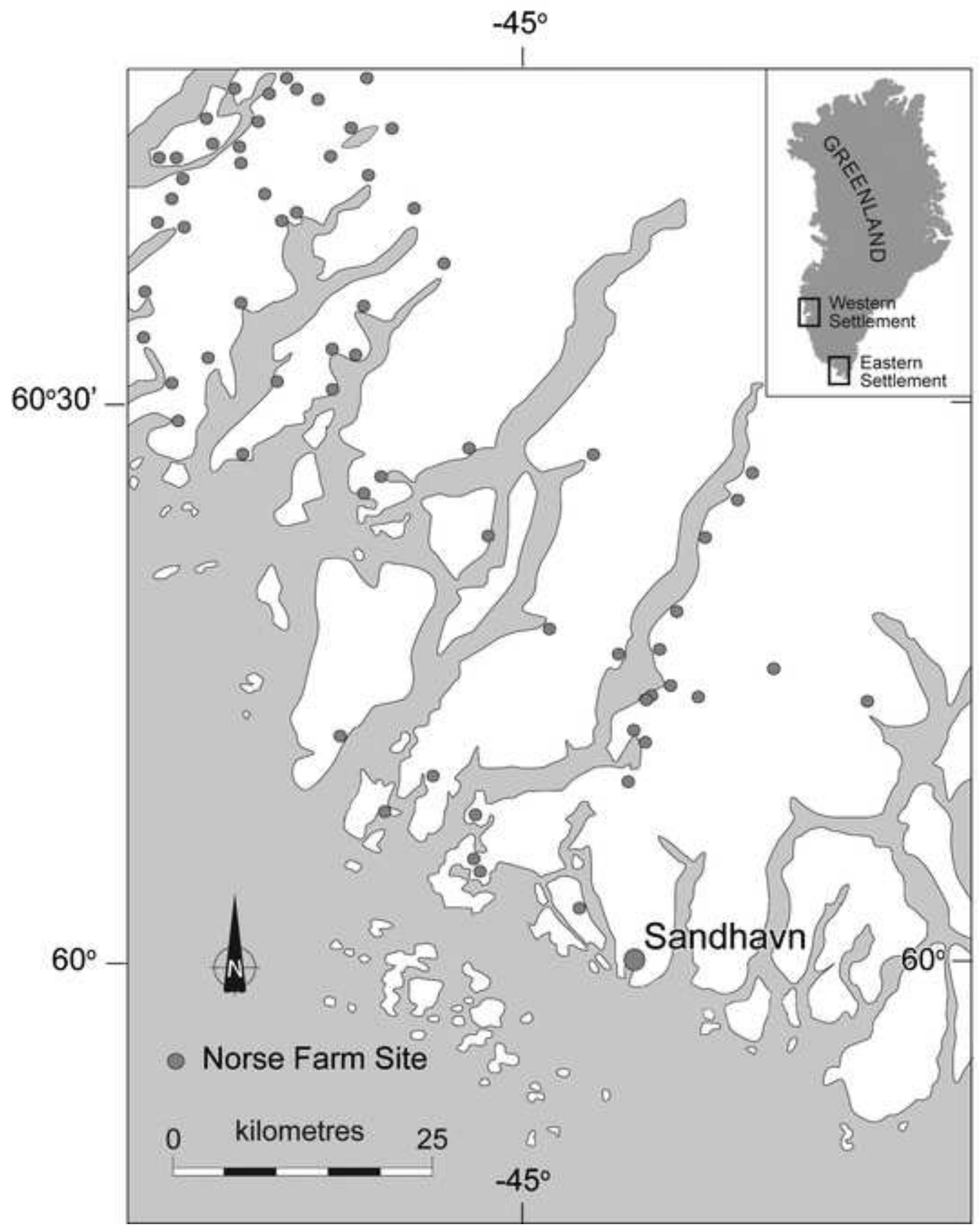




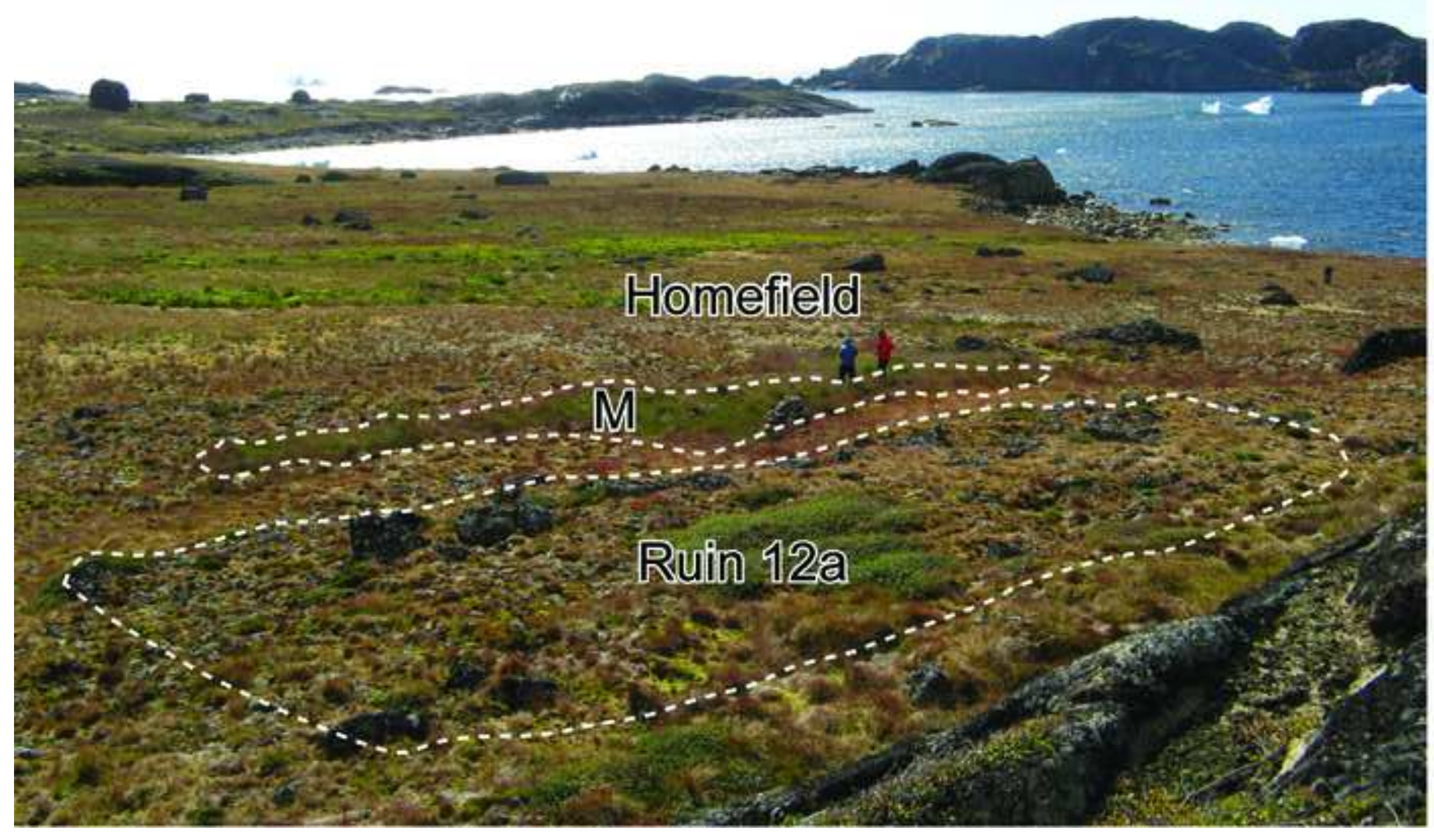


$\sim$ River/Stream

$\therefore$ Sand/Beach

- Irrigation channel

a Soil pit

Lower homefield

\section{Midden (4)}

Homefield profile 2 (3) (possible) Dam $c^{\prime}$

Irrigation profile 1 (4)

\section{: Upper homefield}

Homefield profile 4 (2)

Homefield profile 3 (2) 
Homefield profile 1 (HP1)

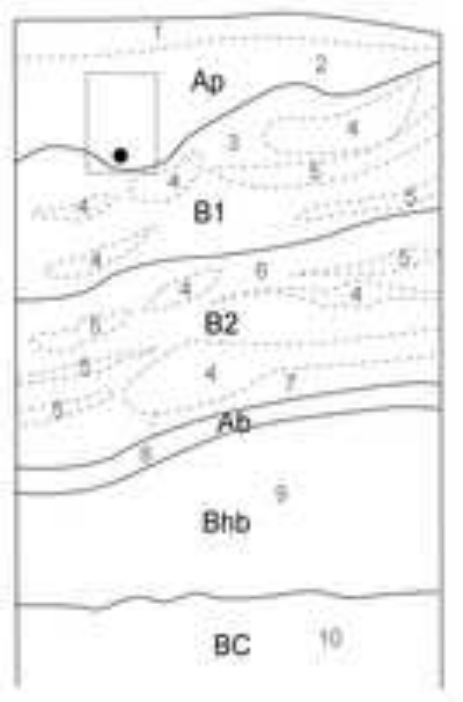

$10 \mathrm{~cm}$

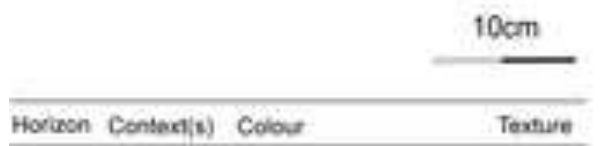

Howion Contextis) Colov

\begin{tabular}{|c|c|c|c|}
\hline As & 1,2 & Brown & st \\
\hline 8t & 3 & Greyish brown & $s$ \\
\hline$B 2$ & 6 & Derk yelowhen brown & s \\
\hline As: & 8 & Very dark Brown & st \\
\hline$B 20$ & $\theta$ & Dark brown & $s$ \\
\hline$B C$ & 10 & Dark nilowith bown & s \\
\hline - & $4 ; 5$ & Verr dark trown & sL \\
\hline- & 7 & Wery dack greyish brown & $s$ \\
\hline
\end{tabular}

- SulRC 21893 es5r30 BP, cal AD $1260-1400$

Homefield profile 2 (HP2)
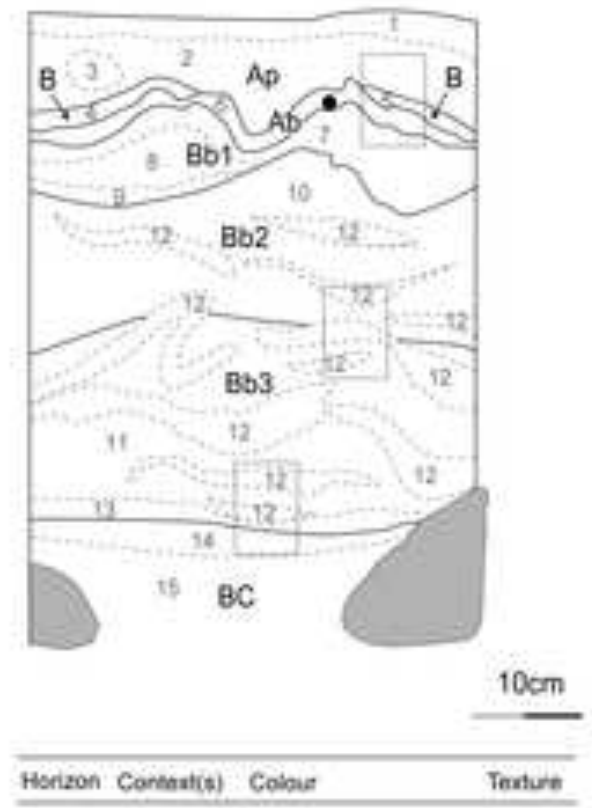

Horizon Contentitis) Coloue Terture

A. 1.23 Dakbrown it

a 4.5 Gevinh brown 5

At 6 Very daikbowm St

Bas 78.9 Cinnabiom 8

Q62 10 Dark yellowish brown is

Db3 It Dark greyiah beown s

eC 14, 15 Dark yelowish brown $\$$

- 12 Veryankbeomn SS2

13 Very dark berown st

- suerac 21903 800430 aP cal No 1040-1230.
Homefield profile 3 (HP3)

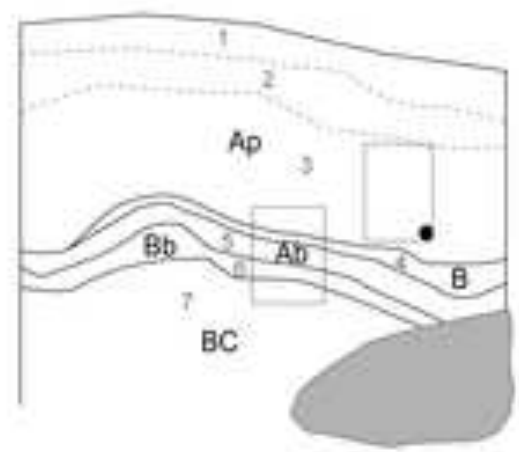

$10 \mathrm{~cm}$

Homefield profile 4 (HP4)
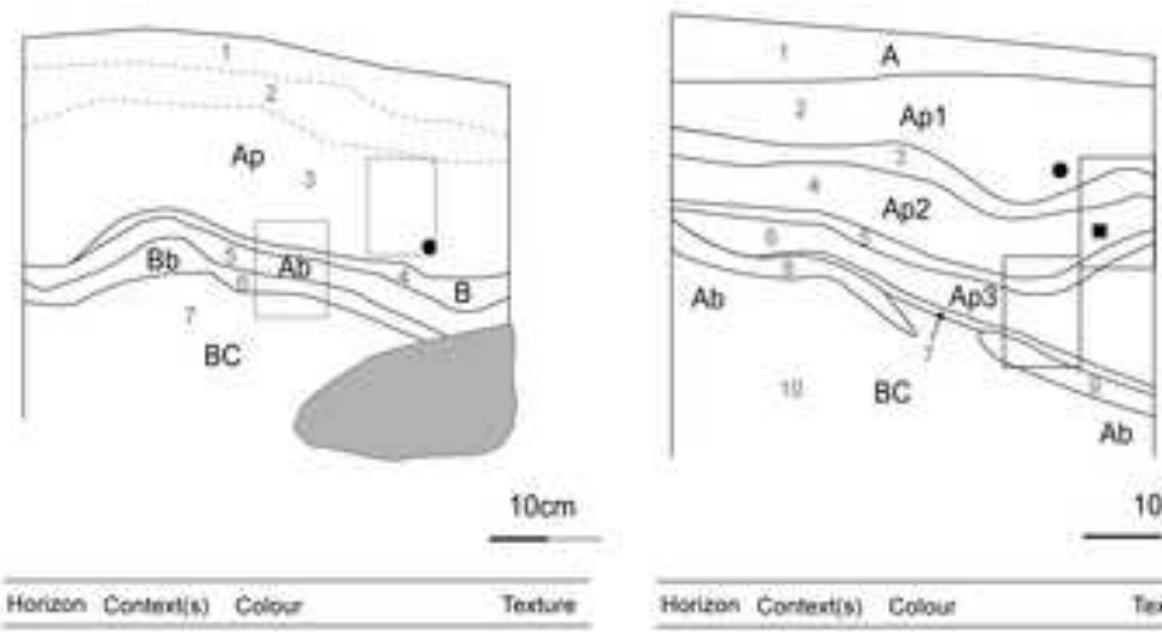

Ap 1.2 .3 Darkbown SSL

B 4 Verydark grevihit brom SsL

Ab 5

ib 0

eleck

Dan gryah brown

Dax ynowiti brewe

- SUERC 21998: 900+30 BP, ON AD 1040-1210
$10 \mathrm{~cm}$

\begin{tabular}{|c|c|c|c|}
\hline Hotizon C & Cortent(s) & Cosove & Terbure \\
\hline A & 1 & Brown & s \\
\hline Ap1 & 2 & Very dark brown & $L$ \\
\hline $\mathrm{An} 2$ & 4 & Very dark trown & $t$ \\
\hline Aps & 0 & Wery dakk brown & $\mathrm{t}$ \\
\hline$A b$ & 8,9 & Black & L \\
\hline$B C$ & 10 & Dark yelowish brown & s \\
\hline . & $3,5,7$ & Darkbeown & $\$$ \\
\hline
\end{tabular}

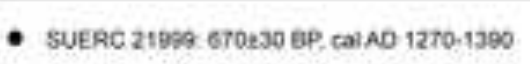

- SUerc 22000 790:30 gP cal AD 11DO-1280. 


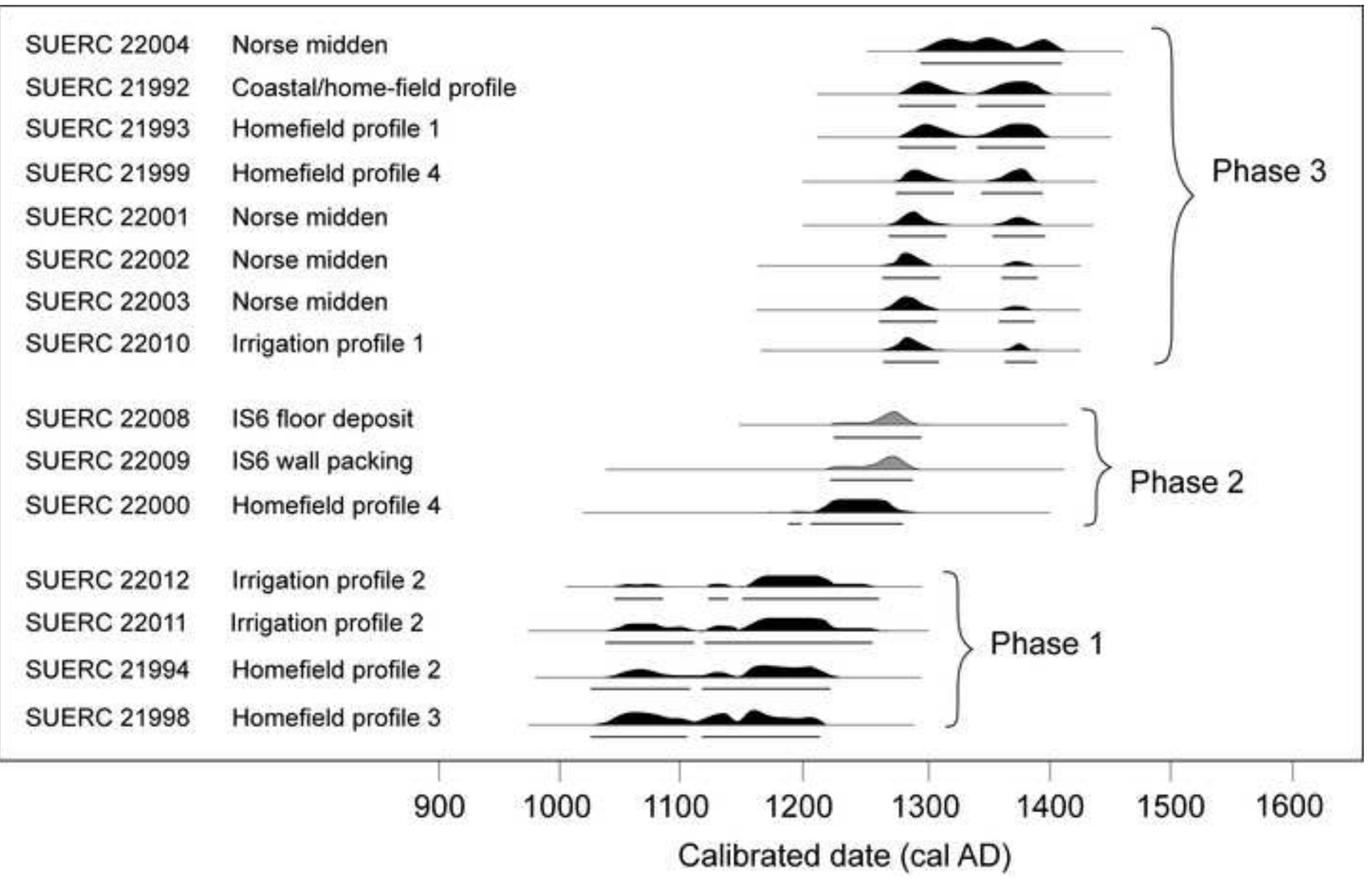



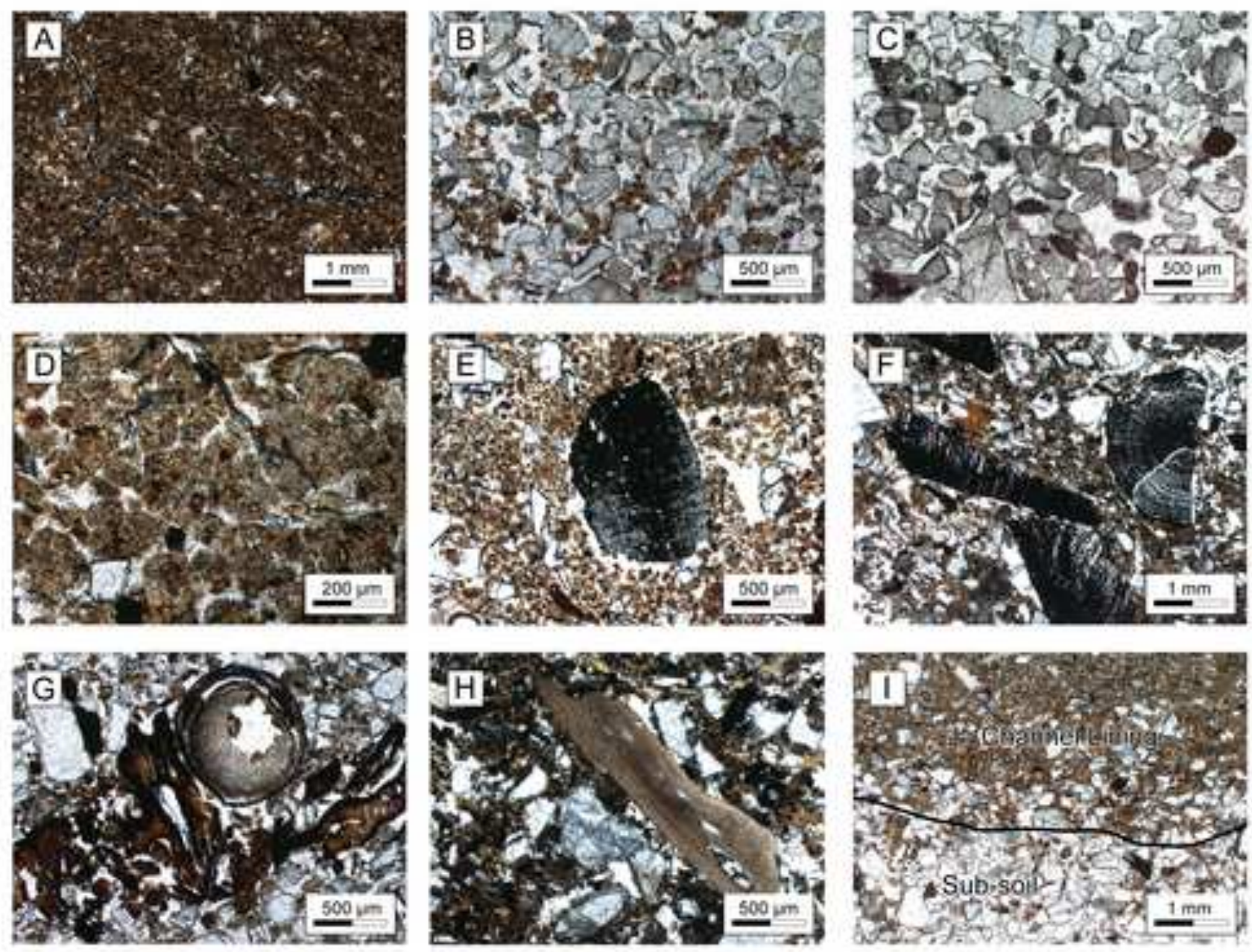


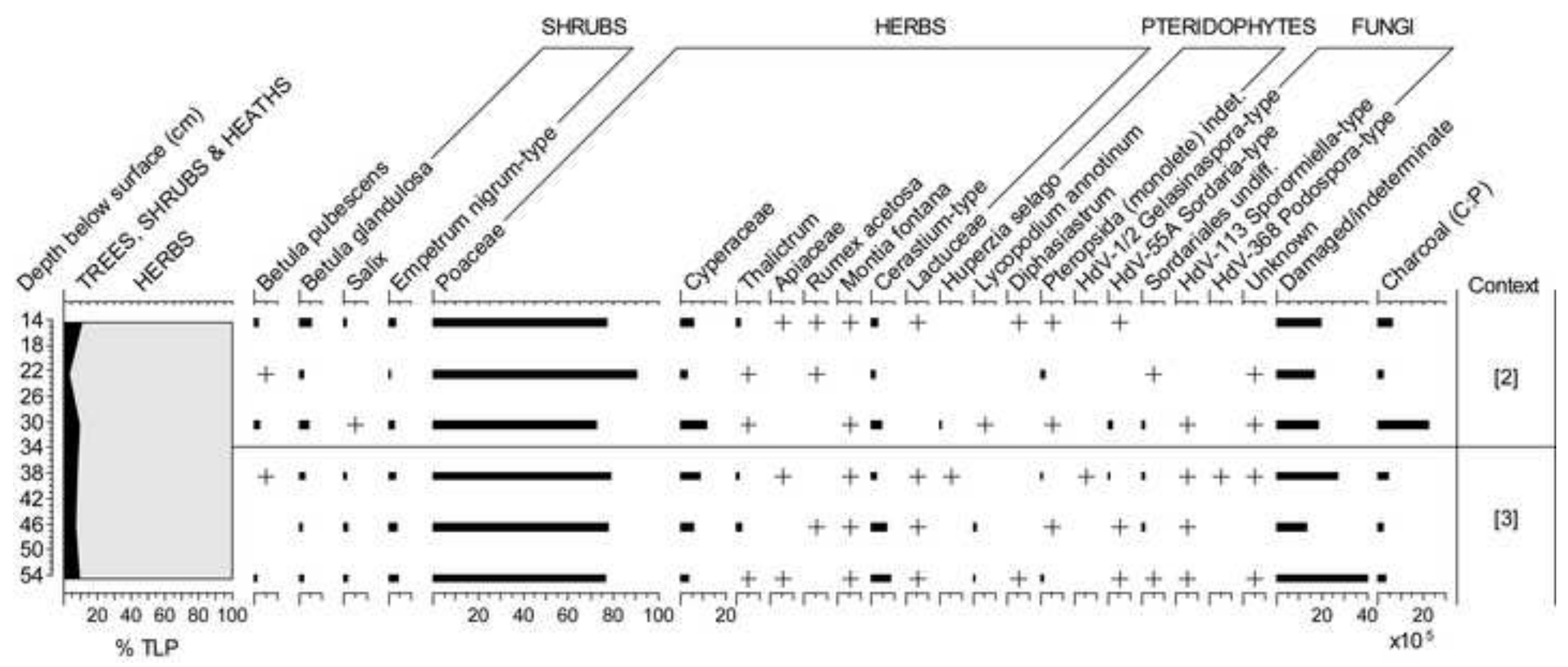




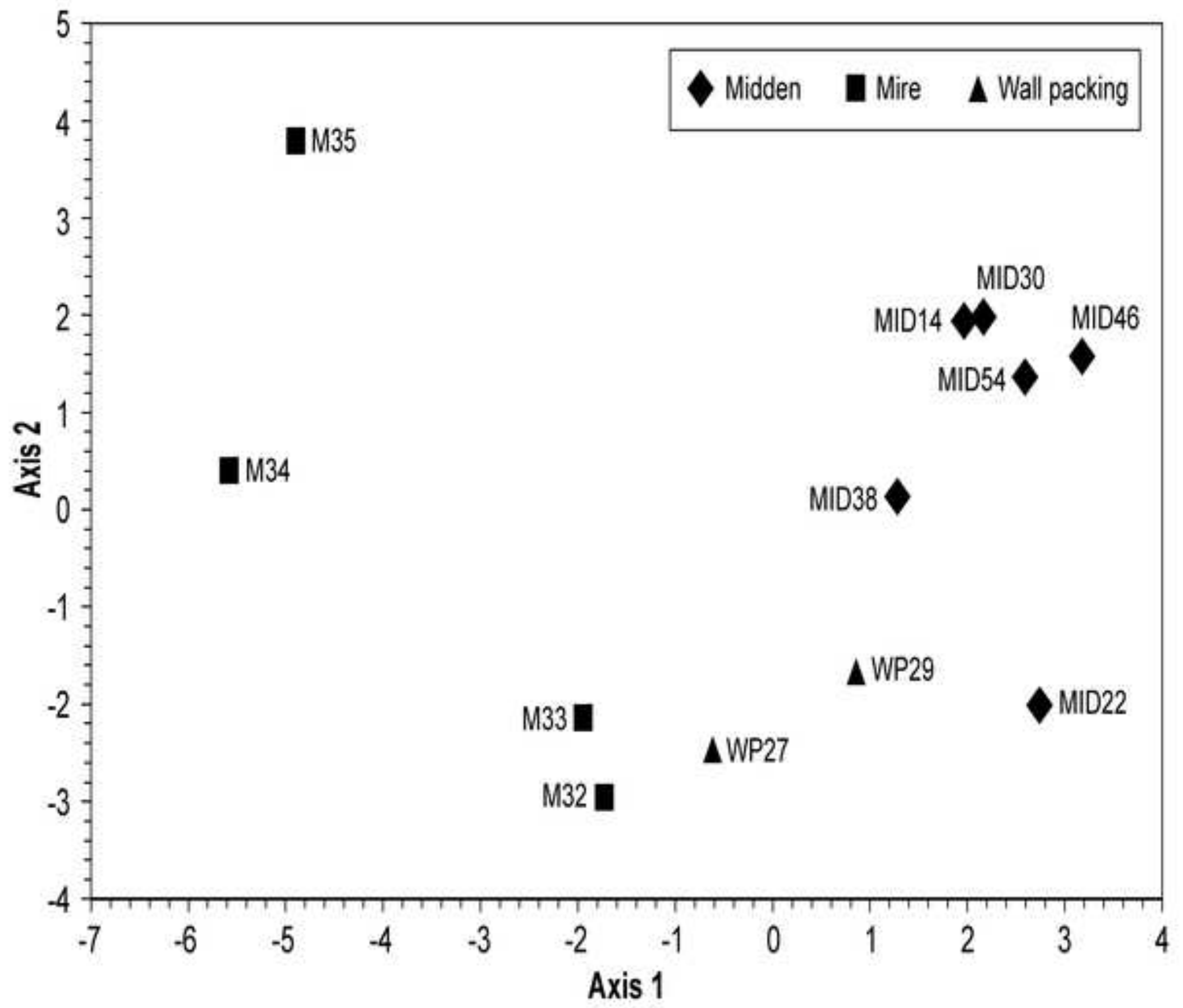




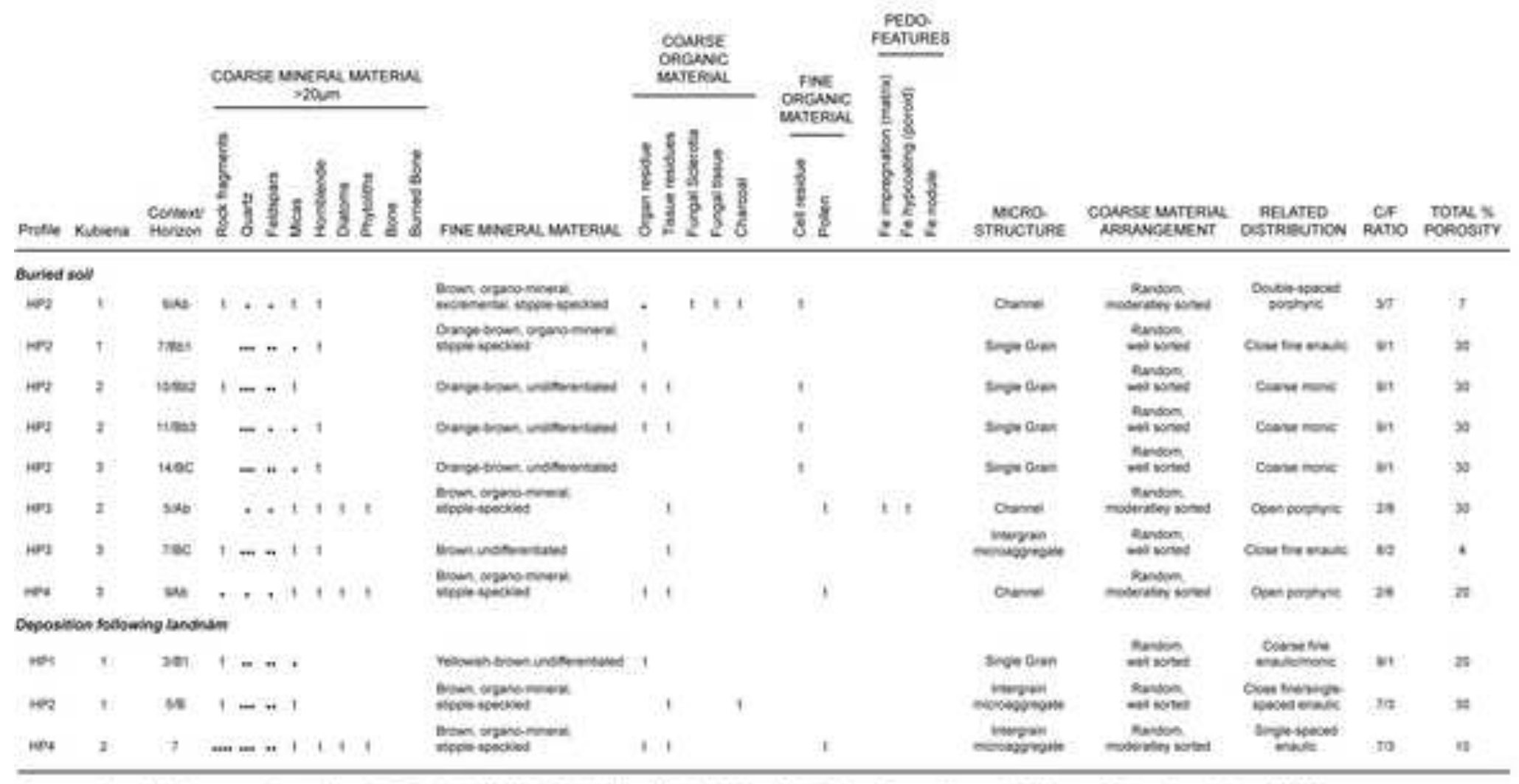

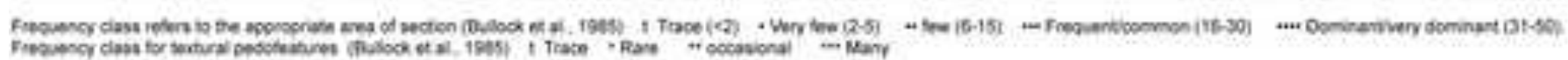




\begin{tabular}{|c|c|c|c|c|c|c|c|c|c|c|c|c|c|}
\hline \multirow[b]{2}{*}{ Profile } & \multirow[b]{2}{*}{ Horizon } & \multicolumn{2}{|c|}{$\begin{array}{c}\text { Charcoal } \\
\text { Abundance }\end{array}$} & \multicolumn{2}{|c|}{$\begin{array}{c}\text { Bone } \\
\text { Abundance }\end{array}$} & \multicolumn{2}{|c|}{$\mathrm{Mg}$} & \multicolumn{2}{|c|}{$P$} & \multicolumn{2}{|c|}{$\mathrm{K}$} & \multicolumn{2}{|c|}{$\mathrm{Ca}$} \\
\hline & & Mean \% & o & Mean \% & $\sigma$ & $\begin{array}{c}\text { Mean } \\
\text { weight } \%\end{array}$ & $\sigma$ & $\begin{array}{c}\text { Mean } \\
\text { weight } \%\end{array}$ & $\sigma$ & $\begin{array}{c}\text { Mean } \\
\text { weight } \%\end{array}$ & $\sigma$ & $\begin{array}{c}\text { Mean } \\
\text { weight } \%\end{array}$ & $\sigma$ \\
\hline A HP1 & Ap & 1.5 & 2.3 & - & - & $0.02^{\mathrm{bc}}$ & 0.06 & $0.35^{d}$ & 0.08 & $0.28^{a b}$ & 0.34 & $0.31^{b c}$ & 0.28 \\
\hline HP2 & Ap & 1.4 & 2.3 & . & . & $0.02^{\mathrm{bc}}$ & 0.05 & $0.32^{d}$ & 0.15 & $0.16^{b}$ & 0.08 & $0.27^{\mathrm{bc}}$ & 0.08 \\
\hline HP2 & $\mathrm{Ab}$ & 1.2 & 1.5 & - & - & $0.01^{\mathrm{c}}$ & 0.04 & $0.34^{d}$ & 0.18 & $0.49^{a b}$ & 0.83 & $0.35^{b c}$ & 0.20 \\
\hline HP3 & $A p$ & 3.3 & 4.0 & - & - & $<0.01^{c}$ & 0.02 & $0.31^{d}$ & 0.09 & $0.19^{b}$ & 0.16 & $0.24^{\circ}$ & 0.09 \\
\hline HP3 & $\mathrm{Ab}$ & - & - & - & - & $0.04^{\mathrm{bc}}$ & 0.07 & $0.73^{a b c}$ & 0.28 & $0.58^{\mathrm{a}}$ & 0.47 & $0.30^{b c}$ & 0.12 \\
\hline IP1 & 2 & 3.5 & 6.8 & - & . & $0.03^{b c}$ & 0.04 & $0.34^{d}$ & 0.15 & $0.32^{a b}$ & 0.31 & $0.54^{a b c}$ & 1.15 \\
\hline IP2 & 6 & 2.7 & 3.9 & 0.1 & 2.1 & $0.01^{\mathrm{e}}$ & 0.03 & $0.27^{d}$ & 0.11 & $0.18^{b}$ & 0.31 & $0.17^{\circ}$ & 0.06 \\
\hline HP4 & Ap1 & 3.2 & 4.1 & . & - & $0.07^{a b c}$ & 0.07 & $0.50^{\text {bed }}$ & 0.20 & $0.27^{a b}$ & 0.16 & $0.40^{b c}$ & 0.14 \\
\hline HP4 & $\mathrm{Ap2}$ & 4.3 & 5,4 & 0.1 & 1.5 & $0.11^{\mathrm{a}}$ & 0.09 & $0.50^{\text {bod }}$ & 0.20 & $0.34^{a b}$ & 0.24 & $0.47^{\mathrm{bc}}$ & 0.15 \\
\hline HP4 & Aps & 3.2 & 5.0 & - & - & $0.09^{a b}$ & 0.08 & $0.50^{\text {bed }}$ & 0.17 & $0.29^{a b}$ & 0.20 & $0.49 b c$ & 0.30 \\
\hline HP4 & $\mathrm{Ab}$ & . & . & . & - & $0.07^{a b c}$ & 0.08 & $0.42^{\text {cd }}$ & 0.12 & $0.30^{a b}$ & 0.18 & $0.40^{b c}$ & 0.17 \\
\hline Midden & 2 & 7.3 & 7.9 & 5.6 & 8.8 & $0.09^{a b}$ & 0.16 & $0.80^{a b}$ & 0.43 & $0.34^{a b}$ & 0.48 & $0.84^{a b}$ & 0.59 \\
\hline Midden & 3 & 5.4 & 8.1 & 2.4 & 5.6 & $0.03^{\mathrm{bc}}$ & 0.07 & $0.92^{a}$ & 1.21 & $0.28^{a b}$ & 0.15 & $1.10^{\mathrm{a}}$ & 1.71 \\
\hline
\end{tabular}




\begin{tabular}{|c|c|c|c|c|c|c|c|c|c|c|c|c|c|}
\hline \multirow[b]{2}{*}{ Protis } & \multirow[b]{2}{*}{ notiens } & \multirow[b]{2}{*}{$\begin{array}{l}\text { conten: } \\
\text { nowisos }\end{array}$} & 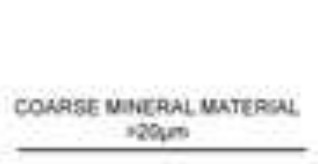 & \multirow[b]{2}{*}{ FAE WNAERAL MATERULL } & \multicolumn{2}{|c|}{$\begin{array}{l}\text { copese } \\
\text { chowic } \\
\text { watericic }\end{array}$} & \multirow{2}{*}{ 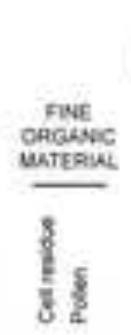 } & \multirow{2}{*}{ 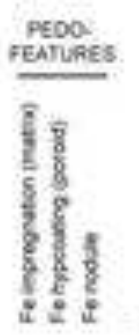 } & \multirow[b]{2}{*}{$\begin{array}{l}\text { U.CSO } \\
\text { STHUCTISE }\end{array}$} & \multirow[b]{2}{*}{ 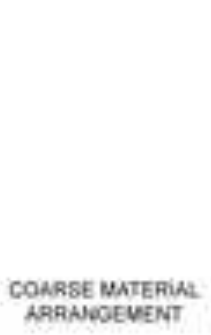 } & \multirow[b]{2}{*}{ 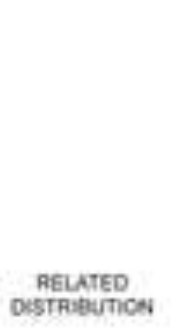 } & \multirow[b]{2}{*}{ OF } & \multirow[b]{2}{*}{$\begin{array}{l}\text { Tosas st } \\
\text { pospostr }\end{array}$} \\
\hline & & & 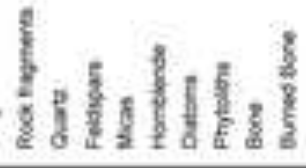 & & है & $\frac{1}{3} \frac{5}{2}$ & & & & & & & \\
\hline \multicolumn{14}{|c|}{ 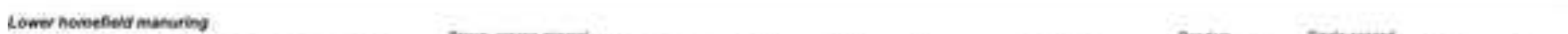 } \\
\hline er & , & 20 & $\cdots+1$, & 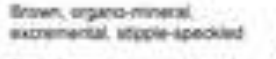 & . & $\therefore$ & 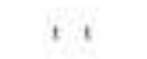 & t & oume & Ponden & $\begin{array}{l}\text { Inge nacest: } \\
\text { somplye }\end{array}$ & $\Leftrightarrow$ & , \\
\hline nes & ' & 240 & $\cdots+1$ & 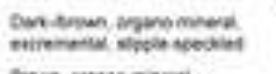 & & 1.1 & 11 & & $n$ & Ponom & 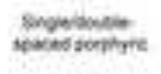 & $n$ & 18 \\
\hline$m$ & s & क्ष & $1 . . .+1$ & 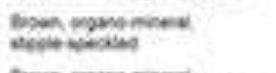 & - & , & , & & mover & $\operatorname{mensin} 1$ & Cout tormens & sa & $\approx$ \\
\hline ens & t & ine & $1 \ldots-1+1$ & 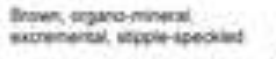 & . . & 11. & 1 & & and & moncosis. & aremiontrs & sT & , \\
\hline nes & 2 & 200 & $\ldots+1, t$ & 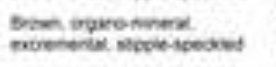 & 1. & $\therefore$ & $t$ & & mosese & nondent. & 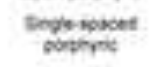 & at & , \\
\hline \multicolumn{14}{|c|}{ unper nomenteld menwing } \\
\hline =e & , & 20,1 & $\therefore \cdots=t+t$ & 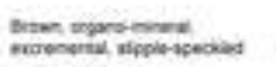 & 1. & $1=$ & t 1 & & Ondontest & noush & Inopespose & sa & is \\
\hline te. & , & , & $\ldots \ldots 1$, & 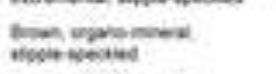 & , & & , & & 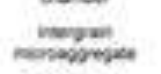 & nimos. & Downesed & na & 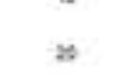 \\
\hline ies & , & Weat & $\ldots \ldots+1$, & 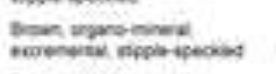 & , . & $\therefore$ & t & & crancieint & nowesens. & songerosed & 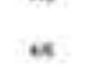 & , \\
\hline if & 1 & , & $=\ldots \ldots=1$, & 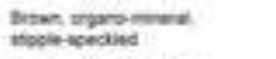 & , & & ' & & necoprosen. & 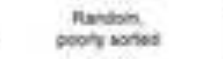 & tronescent & $\mathrm{ma}$ & 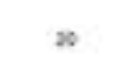 \\
\hline +e4 & 1 & (a)s & $\ldots \ldots$ & 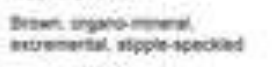 & & $\therefore 1$. & 11 & & consens & trosionses & inverisen & 27 & 3 \\
\hline tes & 2 & and & $\ldots \ldots, 1$ & 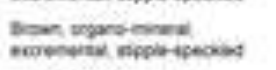 & & 1, & t & & onamaind & nowerenses. & Sorpeneses & $w$ & 3 \\
\hline ate & 2 & 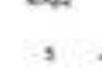 & $=1$, & sum apesind & , & & , & & mexoment & rovidan & ingenseser & $\mathrm{m}$ & 20 \\
\hline$=04$ & I & $\Leftrightarrow$ & $\ldots$ & 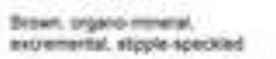 & & & 11 & & consin: & novom & inowed & 27 & , \\
\hline
\end{tabular}

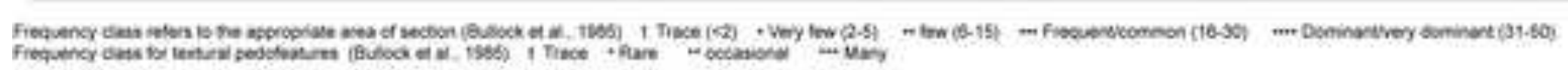




\begin{tabular}{|c|c|c|c|c|c|c|c|c|c|c|c|c|c|c|c|}
\hline Kubiesa & $\begin{array}{l}\text { Conewo } \\
\text { Hertiont }\end{array}$ & \multicolumn{3}{|c|}{ 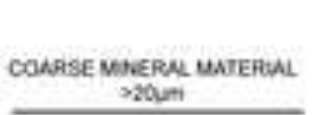 } & \multicolumn{5}{|c|}{$\begin{array}{l}\text { conces } \\
\text { opgesic } \\
\text { vaterest }\end{array}$} & $\begin{array}{l}\text { FNE } \\
\text { CANCANAC } \\
\text { MATERLAL }\end{array}$ & $\begin{array}{l}\text { MCREO } \\
\text { SRUCTUPE }\end{array}$ & $\begin{array}{l}\text { CORASE MUTERUL } \\
\text { MARANGEUEST }\end{array}$ & $\begin{array}{l}\text { RELATED } \\
\text { OIMRIEUTION }\end{array}$ & $\begin{array}{l}\text { CF } \\
\text { putro }\end{array}$ & $\begin{array}{l}\text { Torat \& } \\
\text { PCROSitr }\end{array}$ \\
\hline \multicolumn{16}{|l|}{ Nidaden } \\
\hline+ & 2 & $+\ldots+1$ & 111 & 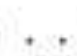 & 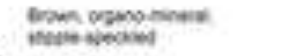 & & 11 & 1. & - & 1 & Vers & Rasos & couponpres & to & 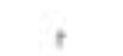 \\
\hline 1 & $20 \mathrm{~d}$ & $1 \ldots 1$ & 1,1 & , & 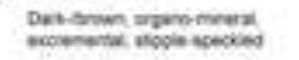 & & ' & & - & 1 & nor. & 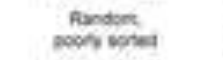 & Dearpophre & ss & + \\
\hline 2 & $z$ & $1=1$ & 1,1 & +1 & 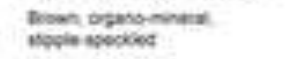 & & 1 & & - & I & var & $\begin{array}{l}\text { Aundos: } \\
\text { nopivisotea }\end{array}$ & Dearporphe & ta & 7 \\
\hline 3 & 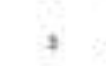 & ... & 1,1 & +1 & 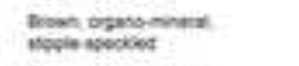 & & 111 & & - & 11 & ner & Poivivion: & Dew poptref & na & 7 \\
\hline 4 & 3 & * * * 1 & 111 & 11 & 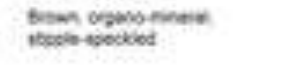 & & & $1 \cdot$ & - & 11 & nor & 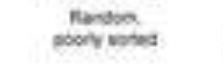 & Dearpoptre & ta & 7 \\
\hline \multicolumn{16}{|c|}{ migastos frotile $t$} \\
\hline 1 & $z$ & $1 \ldots, 1$ & t & & 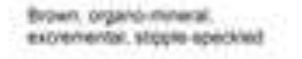 & e' & 1 & 1 & 6 & 1 & new & Hodong & 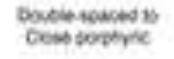 & ou & Q \\
\hline , & $m$ & .... & $t$ & & 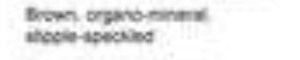 & +1 & $1+1$ & $t$. & - & $t$ & motrasan. & nosurster and & con the nows & st & $n$ \\
\hline 2 & 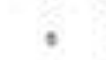 & $1 \ldots$ & +1 & 1 & 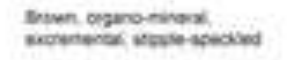 & t. & .1 & $t$. & * & $=t$ & Wort & $\begin{array}{l}\text { Rendon: } \\
\text { sosestery wose }\end{array}$ & Cownoph & st & , \\
\hline 3 & 6 & $1 \ldots+1$ & $t+1$ & 1 & 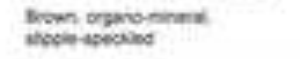 & t. & $\cdot+1$ & $t$ & $t$ & $=1$ & usta & Nondion. & Coumpontre & ns & $T$ \\
\hline
\end{tabular}

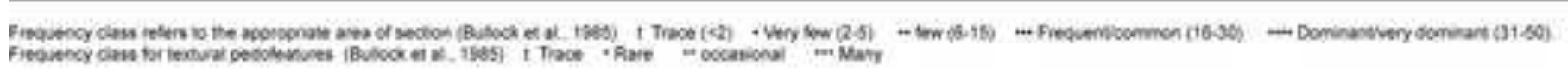

